\title{
SOME PSYCHOLOGICAL FACTORS ASSOCIATED WITH ILLNESS BEHAVIOR AND SELECTED ILLNESSES
}

\author{
Stanislay V. Kasl, Ph.D. and Sidney Cobb, M.D., M.P.H. \\ The University of Michigan Institute for Social Research, Ann Arbor, Michigan
}

(Received 10 June 1963)

THE PERCEPTIVE physician in private practice regularly reports that a substantial proportion of the patients who present themselves to him come for reasons other than the presenting complaint. HALLIDAY [1], on intuitive grounds, called attention to the importance of finding out why the patient with a chronic illness comes today rather than last week or next week, and Stoeckle and Davidson [2] have emphasized the role of depression in this phenomenon. In the last 15 years, interest has spread beyond the clinician with the recognition that the seeking of medical care represents patient behavior which ought to be studied in its own right. Evidence of this broadening perspective can be seen in diverse areas: (1) in the problems selected for study: PaRsons' [3] work on the role of medical science in modern society, Koos' [4] community study, the numerous surveys on the use of a new drug or vaccine $[5,6]$, studies of attitudes towards doctors and medicine $[7,8]$, and the concern with the problem of self-referral [9]; (2) the wide usage of new terms: medical sociology, social psychiatry, sick role, and lately, illness behavior [10]; (3) the appearance of more specialized publications: JAco's Patients, Physicians, and Illness [11], KING's Perception of Illness and Medical Practice [12], or the new Journal of Health and Human Behavior.

The terms sick role and illness behavior are broad terms intended to characterize a domain of interest which covers both the person's actual state of health and the health action he undertakes. More specifically, we might see illness behavior in the framework of a pattern of interacting variables: (1) objective health; (2) perceived or experienced health; (3) evaluation of perceived health; and (4) an action decision based upon the evaluation. Moreover, each of the above variables will reflect, in a particular instance, a complex of other determinants. An action decision, for example, may be influenced by: (a) awareness of various action possibilities; (b) perceived probability of the efficacy of an action; (c) the cost, broadly speaking, of taking such action; (d) the cost or consequences of taking no action, and so on [13].

In the present paper, the reader will first be introduced to some past studies dealing with one important type of illness behavior, visits to a free medical facility. In the next step, the design and purpose of the present study will be outlined. In this study, the major assessment variables are disturbances of mood (reported well-being) and self-report measures of aggressive tendencies and of control over 
impulsiveness and over feelings of anger. These variables are studied in their relationship to illness behavior and to several diagnosed illnesses.

PAST RESEARCH ON ILLNESS BEHAVIOR

The studies under consideration are primarily concerned with factors which are related to the utilization rates for a free medical facility. Mechanic and VolKarT [14] used reported frequency of feelings of loneliness and nervousness and a measure of the tendency to adopt the sick role, namely the willingness to seek medical aid in various hypothetical situations, to predict the frequency of visits to a University medical facility among male freshmen. Both variables were positively but mildly related to the frequency of dispensary visits. It is not known what proportion of students were seeking purely psychological help in coming to the dispensary. In a companion article [15], the same authors present supporting evidence for the hypothesis that students with a strong tendency to adopt the sick role will be over-represented in illnesses which are common in that population, which are relatively familiar, and which have a predictable outcome. However, the variable of perceived stress was not found related, in any consistent fashion, to the same illnesses.

In another study of college freshmen, RoESSLER and GREENFIELD [16] showed that low self-acceptance, assessed from a self-report measure as well as from subsequent evidence of suicide attempts, is associated with higher rates of applying for medical care. One interpretation of the results might be that bodily distress leads both to low self-acceptance and to the seeking of medical aid. The authors feel this interpretation may be discounted because of the design of the study: at the time at which self-acceptance was assessed, the subjects did not experience or report bodily distress. The results of still another study [17], however, reveal generally inconsistent relationships between medical visits and many indices of adjustment, collected on three different populations.

Turning now to studies of illness behavior in an industrial setting [18, 19], we find strong negative relationships between occupational status and the frequency of dispensary visits. These rates excluded visits for injuries and were corrected for age and for distance to the medical department. The data were collected on male employees at two different companies and the inverse correlation between an cmployec's rate of dispensary visits and the status-skill level of his job held within the different subject populations of craftsmen, foremen, second line supervisors, and white collar workers. The rates of visits at two different periods of time for men who had remained on the same job showed positive correlation of 0.95 reflecting the high temporal stability of this index. For men who had switched jobs, the reliability of the index was significantly lower. More specifically, men who moved to higher jobs showed a decrease in dispensary visits, whereas men moving down showed an increase. The original publications offer a detailed discussion of the numerous possible biases which must be considered and ruled out as one interprets these data. Two such possible biases, which were considered and ruled out as improbable or insufficient explanations, are (1) a more rapid promotion of the healthier men, and (2) lower rates of visits to company dispensary being compensated by higher rates of visits to private physicians.

The above results are corroborated in a somewhat different setting and with a 
different measure of illness behavior: among civil service employees, there was an inverse linear relationship between the frequency of short-term sick leaves and the grade of the job [20]. That is, employees on higher grade jobs lost fewer days from work.

At this point, the question might be raised: how can the sample of results discussed above be fitted into some kind of a theoretical framework? The data relating dispensary visits to occupational status are consistent with studies which have shown lower rates of hospitalization for the diagnosis of schizophrenia [21] and higher job satisfaction in higher skill jobs [22]. KASL and FreNCH [19] have suggested a theoretical framework within which these diverse effects of status can be interpreted. They assumed that characteristics of job occupants can be inferred from the characteristics of their jobs and that, consequently, men on higher status jobs are more highly esteemed by the general public. This high level of public esteem leads to high self-esteem, which should then be associated with infrequent illness behavior. In accordance with the above analysis, men on higher status jobs had higher self-esteem and men with higher self-esteem had fewer dispensary visits [19].

It thus appears that self-esteem, self-evaluation, or self-acceptance, are important correlates of illness behavior. This generalization, though plausible on the basis of the above results and from clinical observations [2], has several limitations: (1) The correlation between self-esteem and illness behavior itself represents a relationship which must be studied in great detail. In a real sense, it raises more questions than it answers. For example, is self-esteem related to physiological changes which lead to organic malfunction or does self-esteem primarily affect the individual's perception of his health and the evaluation of this perception? (2) To what extent is the psychological construct of self-esteem the most suitable one? Does it refer to superficial behavior or does it represent some underlying unity? That is, might one not use another construct, such as strength of frustration, which would be even more useful in studying this problem? (3) Correlates other than self-esteem may be highly important. It was found, for example, that the perception of one's job as dull and monotonous wus positively related, independently of selfesteem, to dispensary visits [19]. (4) The index of dispensary visits is a global measure and it may well be that self-esteem is related only to certain kinds of dispensary visits. Nevertheless, the global measure does probably yield a meaningful and useful index, inasmuch as there is some evidence $[23,24]$ that those subjects who experience the greatest number of episodes of illness will do so for a great diversity of illnesses; that is, such subjects seem to show an increased susceptibility to illness in general.

THE PRESENT STUDY

In view of the above limitations, it seemed desirable to explore additional possible correlates of illness behravior. More specifically, this study focuses on three groups of psychological variables and their relationships to dispensary visits, illness absences, and several diagnostic categories: (1) disturbances of mood and reported well-being; (2) reported aggressive tendencies; and (3) reported control over impulses and over feelings of anger. The interest in anger and aggression stems from: (a) the belief, commonly expressed in the psychological literature, that the expression and 
control of anger-aggression are important correlates of mental and physical health; (b) the hope that one may eventually be able to link self-esteem with angeraggression; that is, low occupational status may lead to higher frustration, which may then be associated, given suitable conditions, with the arousal of anger and aggression $[25,26]$. The theory and data linking occupational status and self-esteem have already been presented.

The data were collected at a large company which is in fact a research laboratory run by a nation-wide corporation. The 331 male subjects in the study were 269 blue-collar workers and 62 foremen, second line supervisors, inspectors, and lower status white-collar workers. The men work in a geographically self-contained unit. This unit is concerned with general maintenance and the work ranges from the taking care of the grounds to the building and repair of large-scale heavy equipment. The mean age of the subjects is 44.3 years, their mean education is 9.5 years and they have worked for the company an average of 9.1 years.

The data come from several sources: (1) company medical and personnel records, covering a 2-year period; (2) physical examinations and medical interviews given to the men in the sample, above and beyond the customary activities of the company medical department; (3) test and questionnaire data. The company records yield absence data, broken down for illness and for personal leave, and rates for dispensary visits, broken down for job-connected injuries and for illness.

Dispensary visits for illness is the variable which is of greatest interest in the study. At the company in question, a somewhat unusual situation exists in that the men are encouraged to freely use the dispensary for any complaints they may have, even if such complaints are not obviously connected with activities on the job. This practice began because in the early days, the dangers of radiation exposure were little understood and the medical staff was anxious to see all kinds of medical problems which might possibly be related. The medical staff has ranged in size from one doctor per 1500 employees to one doctor per 1000 employees, which is above average for most plants.

In terms of the analysis of illness behavior offered in the introduction, a dispensary visit represents an instance of positive action, to which other variables, such as objective health, perceived health, evaluation of the perception, and so on, have contributed in unknown proportions. In addition to using the frequency of dispensary visits for illness, an index was constructed which might more broadly reflect general illness behavior. It combines dispensary visits for illness with illness absences in the following way :

1. Rare illness behavior. Men below the mean of 20 dispensary visits for illness and with one or no illness absences for the period of 2 years.

2. Intermediate illness behavior. Men below the mean on dispensary visits for illness and with two or more illness absences; or men above the mean on dispensary visits for illness and with one or no illness absences.

3. Frequent illness behavior. Men above the mean on dispensary visits for illness and with two or more illness absences.

The diagnostic data, based on periodic examinations and screening interviews plus special examinations, are not confounded by willingness or propensity to come to the dispensary since the refusal rates were negligible. These data were collected as part of a long-term epidemiological and methodological investigation, conducted 
by one of the authors (S.C.) in collaboration with the medical director of the company. Information was available on the following diagnostic categories:

Hernia. This was diagnosed from existing medical records; it is one of the points routinely examined in the periodic physical examination.

Rheumatoid arthritis. The diagnosis of rheumatoid arthritis was made in accordance with the diagnostic criteria of the American Rheumatism Association 1958 Revision [27]. This population was under continuous observation for 28 months, during which period 20 screenings for arthritis were accomplished so that a much higher proportion of those intermittently affected by rheumatoid arthritis was identified than has ever been the case in any previous survey. For further details, see LinCOLN and COBB [28]. A positive diagnosis of rheumatoid arthritis, as discussed later in the text, combines 'probable' and 'definite' diagnosis [27].

Ulcer. A diagnosis of ulcer was considered positive if it was confirmed at operation or by X-ray, or if the individual reported a prolonged period of treatment for his ulcer even though no satisfactory X-ray confirmation had been obtained. Three screening techniques were used to uncover people with ulcer. The first was an examination of the medical records. The second was the use of DunN's Interview Index [29]. The third was a separate inquiry, made by the nurse, of each man in the study. Whenever these sources disagreed, a specific medical investigation was conducted to establish the correct diagnosis. Of the confirmed ulcers, all but one was duodenal in location.

Hypertension. The diagnosis of hypertension was made solely on the basis of diastolic blood pressure. The diagnosis was considered positive if the individual in question had two or more diastolic blood pressures recorded in his company medical record at $92 \mathrm{~mm} \mathrm{Hg}$ or higher.

Obesity. The degree of obesity was based on the ratio of maximum weight to optimum body weight for height at age 25 . The optimum was determined from the tables published by the Metropolitan Life Insurance Company [30]. A man who had at some time during his employment been 30 per cent or more over optimum body weight was defined as obese.

The test information available on the men in the sample consists of scores on the CLYDE Mood Scale $[31,32]$ and answers to a questionnaire dealing chiefly with the expression and control of feelings of hostility and irritation. The tests were administered individually under the supervision of a nurse.

The Clyde Mood Scale consists of 133 items, printed on individual cards. Each item describes a mood-excited, frustrated, cheerful-or a personal characteristicobedient, cooperative - and the subject decides how often or how much he feels the way the item indicates: (1) not at all; (2) a little; (3) quite a bit; (4) extremely. CLYDE factor-analyzed the responses of 200 subjects and obtained six factors. The following are the principal items which characterize each of the six factors:

1. Friendly: friendly, agreeable, cheerful, good-natured.

2. Energetic: energetic, lively, active, wide awake.

3. Clearthinking: clearthinking, able to concentrate, efficient, alert.

4. Aggressive : daring, bossy, forceful, bold.

5. Jittery : jittery, excitable, shaky, calm (negative weight).

6. Depressed : depressed, troubled, unhappy, downhearted. 
In connection with this test, several remarks are in order. First, the six factors appear to form two clusters. One cluster is defined by the first three factors; it contains items which consist largely of personal characteristics, not mood, and appear to be especially heavily loaded on social desirability [33]. The other cluster is defined by the 'Jittery' and 'Depressed' scales; the 'Aggressive' scale apparently belongs to neither cluster. Secondly, many items in this test bear a strong resemblance to the content of many currently used 'adjustment' inventories. Thirdly, the validity information on this test is very limited, but its reproducibility appears to be good. The last point may indicate that the test refiects more pervasive personality characteristics than the label 'Mood Scale' would ordinarily suggest.

The questionnaire items, dealing with impulsiveness and with the expression and control of feelings of anger, hostility, and irritation were put together to form three scales. These scales were formed largely on the basis of similarity of content. The scales and their items are listed below. The answers in parentheses are those which lead to high scores on these scales.

\section{Scale A. Reported tendency to engage in overt aggressive behavior}

1. Sometimes I feel like swearing (True)

2. Sometimes I feel like smashing things (True)

3. I am often said to be a hothead (True)

4. At times I feel like picking a fight with someone (True)

5. I am said to have a temper now (True)

6. When you are furious, what would you do? (Swear, hit or kick something or somebody; clench fist)

Scale B. Reported tendency to behave in an impulsive, uncontrolled manner

1. I am apt to show off if I get a chance (True)

2. I keep out of trouble at all costs (False)

3. Sometimes I pretend to know more than I really do (True)

4. I like large noisy parties (True)

5. I often act on the spur of the moment without stopping to think (True)

Scale C. Reported freedom to experience feelings, especially anger and annoyance

1. How freely do you express your emotions? (Freely; most of the time)

2. When was the last time you were really angry? (Last week; last month)

3. When angry, how long does your anger last? (Few hours, few days or more)

4. How often do you feel a little angry or annoyed? (Quite often, sometimes)

5. How often do you feel irritated or annoyed? (A great deal of the time, some of the time). This question was not asked at the same time that the questionnaire was administered. The correlation between this item and \# 4 is only 0.37 . Obviously the two items do not duplicate each other very much. The relatively low correlation may be partly attributed to (a) the difference in time of administration and (b) the slight change in wording.

The three scales intercorrelate as follows: A with $\mathrm{B}, r=0.43$; A with $\mathrm{C}, r=0.42$; $B$ with $C, r=0.38$. Information about the intercorrelations of individual items within each scale is somewhat difficult to summarize and report because most of the items are scored dichotomously and have widely disparate marginals. Thus, no adequate comparable indices of amount of association can be given. Suffice it to note, then, that for Scale A, all 15 item intercorrelations are significant; for Scale B, 9 out of 
10 are significant; and for Scale C, 7 out of 10 . Thus, it may be assumed that on an index of internal consistency, Scale A would be the highest and Scale $\mathrm{C}$ the lowest. These data are based on 307 men and thus a rather small amount of association will produce a significant result. Two additional points must be emphasized: (1) the labels assigned to these scales are very tentative and should be looked at as convenient summaries of the apparent content of the items rather than any indications of their validity; (2) because of the keying of 10 of the 11 items in Scales A and B, the tendency to acquiesce [34] may contribute an unknown amount of variance.

\section{RESULTS}

It is instructive to report some of the results in the same sequence in which the analysis of the data was carried out. In this way, the reader can see to what extent the approach has been exploratory, rather than determined by theoretical expectations.

In the discussion of previous studies, it was noted that in two different companies dispensary visits for illness were inversely related to occupational status [19]. In the present study, the craftsmen's rates of dispensary visits for illness were not related to the skill level of their jobs. In attempting to understand this failure to duplicate the inverse relationships obtained at the other two companies, one must note certain differences between them and the present company. Two are salient: (1) in the group here studied, the range of skill levels was more restricted; (2) the skill level of the craft jobs was probably not a good indicator of public esteem and self-esteem. At this company, because of its research orientation, the high skill craftsmen are clearly subservient to the scientists who run the organization and to whom alone the 'product' of the company, research data, is fully understandable. Moreover, the scientists make strong demands on the craftsmen in such guises as time pressures and sudden changes in specifications, while perhaps not giving these craftsmen adequate recognition and credit for the work they do.

These points suggested that in seeking to understand the determinants of dispensary visits, one might profitably look at some of the variables which might reflect the supposed frustrations and dissatisfactions of certain of the craftsmen. Specifically, it was hypothesized that when the effects of job status are held constant, the men on the more 'frustrating' jobs would have more dispensary visits for illness.

In the first step, one of the authors (S.C.) selected a number of so-called machineshop jobs where, his knowledge of the company led him to believe, the craftsmen might be especially frustrated and dissatisfied. This selection was done independently of any knowledge of the other data. The 86 men on these machine shop jobs were then contrasted with the 45 men who were on all the other jobs of comparable status level. These two groups did not differ in respect of age or education. In the next step, the two groups were compared on three Clyde Mood Scales: Jittery, Depressed, and Aggressive. These scales should best indicate unpleasant moods which may reflect the supposed differences in job environment. The men on the machine-shop jobs had higher scores on all three scales (at $P<0.001$ or better) than men on the other jobs of comparable status. This then is independent evidence, supporting the observations of one of the authors, that the two groups of jobs are different. 
The data on dispensary visits for illness mildly support the hypothesis: the 86 men on the machine shop jobs had 16.7 per cent $(P=0.03)$ more visits for illness than the 45 men on the remaining jobs.

The notion that the men on the machine shop jobs are more dissatisfied and frustrated suggested that these men would report more irritation and annoyance, as measured by Item 5, Scale C. At this time, the other questionnaire data were unavailable. This prediction was clearly not supported. However, it was found that the frequency of irritation and annoyance was related, among the men in the machine shops, to dispensary visits for illness $(r=0.33, P<0.0001, N=82)$ and to the number of illness absences $(\tau=0.26, P<0.001)$. These correlations were higher, albeit not significantly so, than the corresponding values $(r=0.15, P<0.01, N=241$, and $\tau=0.14, P<0.01$ ) for all the remaining subjects.

These preliminary results encouraged the belief that the variables with which we were dealing--the different moods, feelings of hostility, the expression of angermight prove fruitful, partial determinants, of illness behavior and, perhaps, of specific illnesses. However, because of the failure of other measures, except the three Mood Scales, to differentiate the machine shop employees from the others, the emphasis of the investigation was shifted from looking at the possible effects of the occupational environment to studying the correlates of certain personality characteristics. That is, the questionnaire measures were seen as reflecting primarily some more or less stable personality predispositions and as being insufficiently sensitive to differences in occupational environment.

Table 1 presents three variables to which the six indices of greatest interest in this study are not related. This presentation of negative results serves to circum-

TABle 1. THE RElationship OF HERNIA, DISPENSARY VISITS FOR INJURIES, AND NUMBER OF TIMES ABSENT ON PERSONAL LEAVE TO INDICES OF MOOD AND ANGER

\begin{tabular}{lcccc}
\hline Variable & \multicolumn{2}{c}{$\begin{array}{c}\text { Chi-square values reflecting degree of } \\
\text { association with: }\end{array}$} & & \\
\cline { 2 - 5 } & Hernia & $\begin{array}{c}\text { Dispensary } \\
\text { visits for injuries }\end{array}$ & $\begin{array}{c}\text { Number of } \\
\text { times absent on } \\
\text { personal leave }\end{array}$ & $\begin{array}{c}\text { Number of } \\
\text { subjects }\end{array}$ \\
\hline $\begin{array}{c}\text { Aggressive, } \\
\text { mood scale }\end{array}$ & $0.28, P>0.50$ & $0.05, P>0.50$ & $2.83, P=0.10$ & 305 \\
$\begin{array}{c}\text { Jittery, } \\
\text { mood scale }\end{array}$ & $0.42, P>0.50$ & $5.85, P<0.05$ & $0.12, P>0.50$ & 305 \\
$\begin{array}{c}\text { Depressed, } \\
\text { mood scale }\end{array}$ & $0.35, P>0.50$ & $0.26, P>0.50$ & $1.05, P>0.30$ & 305 \\
$\begin{array}{c}\text { Scale A: Overt- } \\
\text { aggressiveness }\end{array}$ & $0.49, P>0.50$ & $0.07, P>0.50$ & $0.37, P>0.50$ & 307 \\
$\begin{array}{c}\text { Scale B: } \\
\text { Impulsiveness }\end{array}$ & $0.38, P>0.50$ & $0.09, P>0.50$ & $2.73, P=0.10$ & 307 \\
$\begin{array}{c}\text { Scale C: Anger- } \\
\text { irritation }\end{array}$ & $0.15, P>0.50$ & $0.34, P>0.50$ & $1.09, P>0.20$ & 307 \\
\hline
\end{tabular}

scribe the nature of illness behavior which is predictable from the six indices. The table, then, presents partial data indicating the discriminant validity [35] of the indices.

Hernia was selected because it seems to represent a purely physical ailment, 
the diagnosis of which is made independently of any tendency to frequent the medical dispensary. As predicted, hernia is not related to any of the indices. It was further assumed that the rates of dispensary visits for injuries will be unrelated to the psychological indices; such rates are thought to reflect largely the activities on the job. Table 1 bears out this expectation. The single exception, a small relationship with jitteriness, perhaps makes some sense. However, it could easily represent a chance outcome. The third column of Table 1 demonstrates that personal leave absences also cannot be predicted from the six indices.

Table 2 presents some of the correlates of dispensary visits for illness. The absence of association with age makes the use of adjusted rates in order to remove any possible bias, unnecessary. The correlation with illness absences is rather small and suggests that the two measures are not interchangeable indicators of illness behavior. The relationship with visits for injuries has probably several interpretations. Two of the likely ones are: (1) accidental injuries may occur more often to those who are in poor health; (2) a minor injury may be the ostensible reason for visiting the dispensary, while the underlying reason may be the kind of symptom or complaint that ordinarily leads to an illness visit.

TABLE 2. SOME CORRELATES OF DISPENSARY VISITS FOR ILLNESS

\begin{tabular}{lllc}
\hline No. & \multicolumn{1}{c}{ Variable } & $\begin{array}{c}\text { Amount of } \\
\text { association }\end{array}$ & \multicolumn{1}{c}{$\boldsymbol{P}$} \\
\hline 331 & Age & $r=-0.05$ & n.s. \\
309 & Education & $r=-\mathbf{0 . 0 2}$ & n.s. \\
319 & No. of times absent due to illness & $r=0.28$ & $<0.0001$ \\
319 & No. of days absent due to illness & $r=0.28$ & $<0.0001$ \\
320 & No. of times absent for personal leave & $r=0.15$ & $<0.01$ \\
320 & No. of days absent for personal leave & $r=0.04$ & n.s. \\
331 & Dispensary visits for injuries & $r=0.27$ & $<0.0001$ \\
305 & Rheumatoid arthritis & $r=0.24^{*}$ & $<0.0001$ \\
306 & Pcptic ulcer & $r=0.17$ & $<0.001$ \\
321 & Obesity & $r=-0.03$ & n.s. \\
318 & Hypertension & $r=-0.02$ & n.s. \\
315 & Amount of smoking & $\tau=0.13$ & $<0.01$ \\
305 & Friendly, mood scale & $r=-0.05$ & n.s. \\
305 & Energetic. mood scale & $r=-0.08$ & n.s. \\
305 & Clearthinking, mood scale & $r=-0.02$ & n.s. \\
305 & Aggressive, mood scale & $r=0.16$ & $<0.01$ \\
305 & Jittery, mood scale & $r=0.27$ & $<0.0001$ \\
305 & Depressed, mood scale & $r=0.17$ & $<0.005$ \\
307 & Scale A: Overt aggressiveness & $r=0.26$ & $<0.0001$ \\
307 & Scale B: Impulsiveness & $r=0.10$ & $<0.05$ \\
307 & Scale C: Anger-irritation & $r=0.12$ & $<0.02$ \\
\hline
\end{tabular}

*This is a rank order correlation. computed from grouped data. A tau was used whenever the nature of the data violated the assumptions underlying the computation of a product-moment correlation.

The correlations with the four diagnostic categories suggest that rheumatoid arthritis and ulcer, which are accompanied by evident symptoms of pain or discomfort, are mildly related to dispensary visits. The correlation with rheumatoid arthritis is slightly inflated. The men knew that S.C. was conducting an arthritis study and the arthritics might have come to the dispensary more often than they would have ordinarily done in addition to the dispensary visits they made as part 
of the study. However, obesity and hypertension, two disease entities with no obvious accompanying symptoms of distress, are unrelated to dispensary visits. The small correlation with smoking is ambiguous: smoking may lead to dispensary visits because it adversely affects a person's health or both smoking and dispensary visits may be influenced by the psychological and physical health of the individual.

The first three Mood Scales do not account for any variance. It has already been noted that these highly inter-correlated scales perhaps reflect more the desirable and stable personal characteristics than a pleasant mood. The other three scales show mild, positive correlations between disturbances of mood and rates of dispensary visits. Such correlations may indicate that a dispensary visit for illness is an act whereby the individual attempts to cope with or alleviate unpleasant sensations and moods. It is also possible that unpleasant moods lead to physical symptoms which then are seen as requiring medical attention. It might also be argued that unpleasant physical symptoms lead both to more frequent dispensary visits and to disturbances of mood. Of these possibilities, the last one is less plausible than the other two, since injuries, which may produce unpleasant physical symptoms, do not appear to be appreciably related to these disturbances of mood, as seen in Table 1.

Table 2 also gives the correlations of the three questionnaire scales with dispensary visits for illness. It can readily be seen that only Scale A yields a correlation which may be sufficiently high to be of practical significance.

Table 3 shows the association of the frequency of illness absences with six test

TABle 3. SOME CORRELATES OF ILLNESS ABSENCES

\begin{tabular}{|c|c|c|c|c|}
\hline Variable & $\begin{array}{l}\text { Score on the } \\
\text { variable }\end{array}$ & No. & $\begin{array}{c}\text { Men with } \\
2 \text { or more } \\
\text { illness absences } \\
(\%)\end{array}$ & $\begin{array}{l}\text { Significance of } \\
\% \text { difference }\end{array}$ \\
\hline Aggressive mood & $\begin{array}{l}\text { Low } \\
\text { High } \\
\text { Total }\end{array}$ & $\begin{array}{l}123 \\
180 \\
303 \\
\end{array}$ & $\begin{array}{l}16.3 \\
30.0 \\
24.4 \\
\end{array}$ & $P<0.005$ \\
\hline$\overline{\text { Jittery mood }}$ & $\begin{array}{l}\text { Low } \\
\text { High } \\
\text { Total }\end{array}$ & $\begin{array}{l}179 \\
124 \\
303 \\
\end{array}$ & $\begin{array}{l}19.6 \\
31.5 \\
24.4 \\
\end{array}$ & $P<0.01$ \\
\hline Depressed mood & $\begin{array}{l}\text { Low } \\
\text { High } \\
\text { Total }\end{array}$ & $\begin{array}{l}138 \\
165 \\
303 \\
\end{array}$ & $\begin{array}{l}18.8 \\
29.1 \\
24.4\end{array}$ & $P<0.02$ \\
\hline $\begin{array}{l}\text { Scale A: Overt } \\
\text { aggressiveness }\end{array}$ & $\begin{array}{l}\text { Low } \\
\text { High } \\
\text { Total }\end{array}$ & $\begin{array}{l}117 \\
188 \\
305 \\
\end{array}$ & $\begin{array}{l}16.2 \\
30.3 \\
24.6\end{array}$ & $P<0.005$ \\
\hline $\begin{array}{l}\text { Scale B: } \\
\text { Impulsiveness }\end{array}$ & $\begin{array}{l}\text { Low } \\
\text { High } \\
\text { Total }\end{array}$ & $\begin{array}{l}192 \\
113 \\
305\end{array}$ & $\begin{array}{l}19.3 \\
33.6 \\
24.6\end{array}$ & $P<0.005$ \\
\hline $\begin{array}{l}\text { Scale C: } \\
\text { Anger-irritation }\end{array}$ & $\begin{array}{l}\text { Low } \\
\text { High } \\
\text { Total }\end{array}$ & $\begin{array}{l}142 \\
163 \\
305\end{array}$ & $\begin{array}{l}18.3 \\
30.1 \\
24.6\end{array}$ & $P<0.01$ \\
\hline
\end{tabular}

variables; all six are significantly related. This is in sharp contrast with the nonsignificant relationships with absences for personal leave and dispensary visits for injuries, seen in Table 1. Additional statistical analyses revealed that illness absences are unrelated to age and to education. 
In the previous section, which describes the methodology of this study, it was noted that dispensary visits for illness and illness absences were combined into a single index of illness behavior. This procedure seems justified on the grounds that: (1) the correlation of 0.28 between the two measures suggests they are relatively independent variables; (2) both measures reflect illness behavior, as defined previously; and (3) they are similarly related to the six test variables. Table 4 presents six correlates of this new index of illness behavior. Two measures, Jittery mood and Scale A, show sufficiently large associations to suggest some practical value. The last three lines of Table 4 show the relationship of illness behavior to

TABLE 4. SOME CORRELATES OF A COMPOSITE INDEX OF FREQUENCY OF ILLNESS BEHAVIOR

\begin{tabular}{|c|c|c|c|c|c|c|}
\hline \multirow[b]{2}{*}{ Variable } & \multirow{2}{*}{$\begin{array}{c}\text { Score } \\
\text { on the } \\
\text { variable }\end{array}$} & \multirow[b]{2}{*}{ No. } & \multicolumn{3}{|c|}{$\begin{array}{l}\text { Men in } 3 \text { categories of } \\
\text { frequency of illness behavior }\end{array}$} & \multirow{2}{*}{$\begin{array}{l}\text { Significance } \\
\text { of } \\
\text { differences. } \\
\text { chi-square } \\
\text { analysis } \\
\text { with } 2 \text { d.f. }\end{array}$} \\
\hline & & & $\underset{\%}{\operatorname{Rare}}$ & $\begin{array}{l}\text { Inter- } \\
\text { mediate } \\
\%\end{array}$ & $\begin{array}{l}\text { Frequent } \\
\%\end{array}$ & \\
\hline Aggressive mood & $\begin{array}{l}\text { Low } \\
\text { High } \\
\text { Total }\end{array}$ & $\begin{array}{l}122 \\
180 \\
302\end{array}$ & $\begin{array}{l}48.3 \\
33.0 \\
39.1\end{array}$ & $\begin{array}{l}41.7 \\
45.6 \\
44.0\end{array}$ & $\begin{array}{l}10.0 \\
21.4 \\
16.9\end{array}$ & $\begin{array}{l}\chi^{2}=10.2 \\
P<0.01\end{array}$ \\
\hline Jittery mood & $\begin{array}{l}\text { Low } \\
\text { High } \\
\text { Total }\end{array}$ & $\begin{array}{l}178 \\
124 \\
302\end{array}$ & $\begin{array}{l}46.1 \\
29.0 \\
39.1\end{array}$ & $\begin{array}{l}43.8 \\
44.4 \\
44.0\end{array}$ & $\begin{array}{l}10.1 \\
26.6 \\
16.9\end{array}$ & $\begin{array}{c}x^{2}=17.2 \\
P<0.0001\end{array}$ \\
\hline Depressed mood & $\begin{array}{l}\text { Low } \\
\text { High } \\
\text { Total }\end{array}$ & $\begin{array}{l}137 \\
165 \\
302\end{array}$ & $\begin{array}{l}44.5 \\
34.5 \\
39.1\end{array}$ & $\begin{array}{l}46.7 \\
41.8 \\
44.0\end{array}$ & $\begin{array}{r}8.8 \\
23.7 \\
16.9\end{array}$ & $\begin{array}{l}\chi^{2}=12.1 \\
P<0.005\end{array}$ \\
\hline $\begin{array}{l}\text { Scale } A \text { : Overt } \\
\text { aggressiveness }\end{array}$ & $\begin{array}{l}\text { Low } \\
\text { High } \\
\text { Total }\end{array}$ & $\begin{array}{l}117 \\
188 \\
305\end{array}$ & $\begin{array}{l}53.8 \\
30.9 \\
39.7\end{array}$ & $\begin{array}{l}39.3 \\
46.3 \\
43.6\end{array}$ & $\begin{array}{r}6.8 \\
22.9 \\
16.7\end{array}$ & $\begin{array}{c}\chi^{2}=21.7 \\
P<0.0001\end{array}$ \\
\hline $\begin{array}{l}\text { Scale B : } \\
\text { Impulsiveness }\end{array}$ & $\begin{array}{l}\text { Low } \\
\text { High } \\
\text { Total }\end{array}$ & $\begin{array}{l}192 \\
113 \\
305\end{array}$ & $\begin{array}{l}43.2 \\
33.6 \\
39.7\end{array}$ & $\begin{array}{l}45.3 \\
40.7 \\
43.6\end{array}$ & $\begin{array}{l}11.5 \\
25.7 \\
16.7\end{array}$ & $\begin{array}{l}\chi^{2}=10.6 \\
P=0.005\end{array}$ \\
\hline $\begin{array}{l}\text { Scale C: } \\
\text { Anger-irritation }\end{array}$ & $\begin{array}{l}\text { Low } \\
\text { High } \\
\text { Total }\end{array}$ & $\begin{array}{l}142 \\
163 \\
305\end{array}$ & $\begin{array}{l}44.4 \\
35.6 \\
39.7\end{array}$ & $\begin{array}{l}43.7 \\
43.6 \\
43.6\end{array}$ & $\begin{array}{l}12.0 \\
20.9 \\
16.7\end{array}$ & $\begin{array}{l}x^{2}=5.1 \\
P<0.10\end{array}$ \\
\hline $\begin{array}{l}\text { Combined scale: } \\
\text { Jittery mood } \\
\text { and Scale A }\end{array}$ & $\begin{array}{l}\text { Low } \\
\text { High } \\
\text { Total }\end{array}$ & $\begin{array}{l}183 \\
119 \\
302\end{array}$ & $\begin{array}{l}50.8 \\
21.0 \\
39.1\end{array}$ & $\begin{array}{l}39.3 \\
51.3 \\
44.0\end{array}$ & $\begin{array}{r}9.8 \\
27.7 \\
16.9\end{array}$ & $\begin{array}{l}x^{2}=31.2 \\
P<0.0001\end{array}$ \\
\hline
\end{tabular}

these two measures when they are combined. It might be noted in passing that the chi-square analysis does not take into account the ranking present in the ordinal scales which are used. That is, the same $\chi^{2}$ value would be obtained whether the frequencies were arranged in the order as shown or juxtaposed as Rare, Frequent, and Intermediate. The net effect is that Type II error is slightly inflated and significant changes may be overlooked. However, in Tables 4-8 only one instance of borderline significance is found which calls for a more precise statistical testthe association of Scale $C$ with illness behavior in Table 4. Computing a tau for grouped data shows this association to be significant at the 0.05 level.

If the labels attached to Scales A and B, 'Overt aggressiveness' and 'Impulsiveness', respectively, are reasonably trustworthy, then the following question may be raised. Does the association between overt aggressiveness and illness behavior change, depending on the level of impulsiveness? That is. would one not expect that a 
certain minimal level of impulsiveness is necessary before the association of aggressiveness with illness behavior would become manifest? Table 5 provides the relevant data. The relationship of Scale A to illness behavior, given for the total

TABLE 5. THE EFFECIS OF IMPULSIVENESS ON THE RELAIIONSHIP OF OVERT AGgRESSIVENESS TO THE FREQUENCY OF ILLNESS BEHAVIOR

\begin{tabular}{|c|c|c|c|c|c|c|}
\hline \multirow[b]{2}{*}{ Variable } & \multirow{2}{*}{$\begin{array}{c}\text { Scale } \\
\text { on the } \\
\text { variable }\end{array}$} & \multirow[b]{2}{*}{ No. } & \multicolumn{3}{|c|}{$\begin{array}{l}\text { Men in } 3 \text { categories of } \\
\text { frequency of illness behavior }\end{array}$} & \multirow{2}{*}{$\begin{array}{c}\text { Significance } \\
\text { of } \\
\text { differences. } \\
\text { chi-square } \\
\text { analysis } \\
\text { with } 2 \text { d.f. }\end{array}$} \\
\hline & & & $\underset{\%}{\text { Rare }}$ & $\begin{array}{l}\text { Inter- } \\
\text { mediate } \\
\%\end{array}$ & $\begin{array}{l}\text { Frequent } \\
\quad \%\end{array}$ & \\
\hline \multicolumn{7}{|l|}{ Scale A: Overt } \\
\hline $\begin{array}{l}\text { aggressiveness } \\
\text { (includes only }\end{array}$ & $\begin{array}{l}\text { Low } \\
\text { High }\end{array}$ & $\begin{array}{l}45 \\
46\end{array}$ & $\begin{array}{l}44.4 \\
39.1\end{array}$ & $\begin{array}{l}48.9 \\
50.0\end{array}$ & $\begin{array}{r}6.7 \\
109\end{array}$ & $\begin{array}{c}\chi^{2}=0.6 \\
P>0.70\end{array}$ \\
\hline $\begin{array}{l}\text { (includes only } \\
\text { men low on } \\
\text { impulsiveness) }\end{array}$ & Total & 91 & 41.8 & 49.5 & 8.8 & \\
\hline $\begin{array}{l}\text { Scale A: Overt } \\
\text { aggressiveness } \\
\text { (includes only } \\
\text { men high on } \\
\text { impulsiveness) }\end{array}$ & $\begin{array}{l}\text { Low } \\
\text { High } \\
\text { Total }\end{array}$ & $\begin{array}{r}72 \\
142 \\
214\end{array}$ & $\begin{array}{l}59.7 \\
28.2 \\
38.8\end{array}$ & $\begin{array}{l}33.3 \\
45.1 \\
41.1\end{array}$ & $\begin{array}{r}6.9 \\
26.8 \\
20.1\end{array}$ & $\begin{array}{c}\chi^{2}=23.7 \\
P<0.0001\end{array}$ \\
\hline
\end{tabular}

sample in Table 4, is presented separately for two groups of subjects, selected according to their impulsiveness scores. It can readily be seen that when the men are low on the impulsiveness measure--that is, when they report strong control over their impulses--then overt aggressiveness is unrelated to illness behavior. The relationship appears only when the men are high on the impulsiveness measure. Table 6 presents the data for the three Mood Scales and the same effects of the impulsiveness measure are evident.

Scale C, labeled 'Reported freedom to experience feelings, especially anger and annoyance', may be examined in the same way as Scale B, impulsiveness. That is, Scale $C$ also seems to deal with control, even though the content is different: it is apparent control of feelings of anger and irritation. Subjects with high scores on Scale $\mathrm{C}$ may be viewed as being more easily emotionally aroused. If this interpretation of the scale is reasonably valid, then we might expect to obtain results comparable to those with Scale B. Table 7 presents the results for Scale A and Table 8 , for the three mood scales. With the exception of Scale A, where the difference is not very large, the results confirm the above-expressed expectation that Scales B and C are functionally similar.

The presentation of results now turns to three diagnostic categories, rheumatoid arthritis, hypertension, and ulcer, which are based on examination of each man. The discussion centers around Scales A, B and C inasmuch as the three mood indicators appear unrelated to the diseases in question.

The intent here is to see if Scales A, B and C can be used to differentiate each disease from the other two and from the frequent illness behavior group. In the first step, therefore, all cases with multiple diagnoses were removed. That is, for example, a person receiving a positive diagnosis of ulcer (as defined previously) was retained in the ulcer group only if he received negative diagnosis on rheumatoid 
TABLE 6. THE EFFECTS OF IMPULSIVENESS ON THE RELATIONSHIP OF MOOD TO THE FREQUENCY OF ILLNESS BEHAVIOR

\begin{tabular}{|c|c|c|c|c|c|c|}
\hline \multirow[b]{2}{*}{ Variable } & \multirow{2}{*}{$\begin{array}{c}\text { Score } \\
\text { on the } \\
\text { variable }\end{array}$} & \multirow[b]{2}{*}{ No. } & \multicolumn{3}{|c|}{$\begin{array}{l}\text { Men in } 3 \text { categories of } \\
\text { frequency of illness behavior }\end{array}$} & \multirow{2}{*}{$\begin{array}{l}\text { Significance } \\
\text { of } \\
\text { differences, } \\
\text { chi-square } \\
\text { analysis } \\
\text { with } 2 \text { d.f. }\end{array}$} \\
\hline & & & $\underset{\%}{\text { Rare }}$ & $\begin{array}{c}\text { Inter- } \\
\text { mediate } \\
\%\end{array}$ & $\begin{array}{l}\text { Frequent } \\
\%\end{array}$ & \\
\hline $\begin{array}{l}\text { Aggressive mood } \\
\text { (includes only } \\
\text { men low on } \\
\text { impulsiveness) }\end{array}$ & $\begin{array}{l}\text { Low } \\
\text { High } \\
\text { Total }\end{array}$ & $\begin{array}{l}48 \\
41 \\
89\end{array}$ & $\begin{array}{l}45.8 \\
36.6 \\
41.6\end{array}$ & $\begin{array}{l}41.7 \\
58.5 \\
49.4\end{array}$ & $\begin{array}{r}12.5 \\
4.9 \\
9.0\end{array}$ & $\begin{array}{l}\chi^{2}=3.1 \\
P>0.20\end{array}$ \\
\hline $\begin{array}{l}\text { Aggressive mood } \\
\text { (includes only } \\
\text { men high on } \\
\text { impulsiveness) }\end{array}$ & $\begin{array}{l}\text { Low } \\
\text { High } \\
\text { Total }\end{array}$ & $\begin{array}{r}74 \\
139 \\
213\end{array}$ & $\begin{array}{l}50.0 \\
31.7 \\
38.0\end{array}$ & $\begin{array}{l}41.9 \\
41.7 \\
41.8\end{array}$ & $\begin{array}{r}8.1 \\
26.6 \\
20.2\end{array}$ & $\begin{array}{l}\chi^{2}=11.7 \\
P<0.005\end{array}$ \\
\hline $\begin{array}{l}\text { Jittery mood } \\
\text { (includes only } \\
\text { men low on } \\
\text { impulsiveness) }\end{array}$ & $\begin{array}{l}\text { Low } \\
\text { High } \\
\text { Total }\end{array}$ & $\begin{array}{l}65 \\
24 \\
89\end{array}$ & $\begin{array}{l}43.1 \\
37.5 \\
41.6\end{array}$ & $\begin{array}{l}47.7 \\
54.2 \\
49.4\end{array}$ & $\begin{array}{l}9.2 \\
8.3 \\
9.0\end{array}$ & $\begin{array}{l}x^{2}=0.3 \\
P>0.80\end{array}$ \\
\hline $\begin{array}{l}\text { Jittery mood } \\
\text { (includes only } \\
\text { men high on } \\
\text { impulsiveness) }\end{array}$ & $\begin{array}{l}\text { Low } \\
\text { High } \\
\text { Total }\end{array}$ & $\begin{array}{l}113 \\
100 \\
213\end{array}$ & $\begin{array}{l}47.8 \\
27.0 \\
38.0\end{array}$ & $\begin{array}{l}41.6 \\
42.0 \\
41.8\end{array}$ & $\begin{array}{l}10.6 \\
31.0 \\
20.2\end{array}$ & $\begin{array}{c}\chi^{2}=16.9 \\
P<0.0001\end{array}$ \\
\hline $\begin{array}{l}\text { Depressed mood } \\
\text { (includes only } \\
\text { men low on } \\
\text { impulsiveness) }\end{array}$ & $\begin{array}{l}\text { Low } \\
\text { High } \\
\text { Total }\end{array}$ & $\begin{array}{l}52 \\
37 \\
89\end{array}$ & $\begin{array}{l}48.1 \\
32.4 \\
41.6\end{array}$ & $\begin{array}{l}46.2 \\
54.1 \\
49.4\end{array}$ & $\begin{array}{r}5.8 \\
13.5 \\
9.0\end{array}$ & $\begin{array}{l}\chi^{2}=3.0 \\
P>0.20\end{array}$ \\
\hline $\begin{array}{l}\text { Depressed mood } \\
\text { (includes only } \\
\text { men high on } \\
\text { impulsiveness) }\end{array}$ & $\begin{array}{l}\text { Low } \\
\text { High } \\
\text { Total }\end{array}$ & $\begin{array}{r}85 \\
128 \\
213\end{array}$ & $\begin{array}{l}42.4 \\
35.2 \\
38.0\end{array}$ & $\begin{array}{l}47.1 \\
38.3 \\
41.8\end{array}$ & $\begin{array}{l}10.6 \\
26.6 \\
20.2\end{array}$ & $\begin{array}{l}\chi^{2}=8.1 \\
P<0.02\end{array}$ \\
\hline
\end{tabular}

TABLE 7. THE EFFECTS OF ANGER-IRRITATION ON THE RELATIONSHIP OF OVERT AGGRESSIVENESS TO THE FREQUENCY OF ILLNESS BEHAVIOR

\begin{tabular}{|c|c|c|c|c|c|c|}
\hline \multirow[b]{2}{*}{ Variable } & \multirow{2}{*}{$\begin{array}{l}\text { Score } \\
\text { on the } \\
\text { variable }\end{array}$} & \multirow[b]{2}{*}{ No. } & \multicolumn{3}{|c|}{$\begin{array}{l}\text { Men in } 3 \text { categories of } \\
\text { frequency of illness behavior }\end{array}$} & \multirow{2}{*}{$\begin{array}{c}\text { Significance } \\
\text { of } \\
\text { differences, } \\
\text { chi-square } \\
\text { analysis } \\
\text { with } 2 \text { d.f. }\end{array}$} \\
\hline & & & $\underset{\%}{\operatorname{Rare}}$ & $\begin{array}{l}\text { Inter- } \\
\text { mediate } \\
\%\end{array}$ & $\begin{array}{l}\text { Frequent } \\
\quad \%\end{array}$ & \\
\hline \multicolumn{7}{|l|}{ Scale A : Overt } \\
\hline $\begin{array}{l}\text { aggressiveness } \\
\text { (includes only }\end{array}$ & Low & $\begin{array}{l}77 \\
65\end{array}$ & 51.9 & 41.6 & 6.5 & $\begin{array}{l}x^{2}=6.6 \\
p<005\end{array}$ \\
\hline $\begin{array}{l}\text { (includes only } \\
\text { men low on } \\
\text { anger-irritation) }\end{array}$ & $\begin{array}{l}\text { High } \\
\text { Total }\end{array}$ & $\begin{array}{r}65 \\
142\end{array}$ & $\begin{array}{l}35.4 \\
44.4\end{array}$ & $\begin{array}{l}46.7 \\
43.7\end{array}$ & $\begin{array}{l}18.5 \\
12.0\end{array}$ & \\
\hline \multicolumn{7}{|l|}{ Scale A: Overt } \\
\hline aggressiveness & Low & 40 & 57.5 & 35.0 & 7.5 & $\chi^{2}=12.9$ \\
\hline (includes only & High & 123 & 28.5 & 46.3 & 25.2 & $\hat{P}<0.005$ \\
\hline $\begin{array}{l}\text { men high on } \\
\text { anger-irritation) }\end{array}$ & Total & 163 & 35.6 & 43.6 & 20.9 & \\
\hline
\end{tabular}


TABLE 8. THE EFFECTS OF ANGER-IRRITATION ON THE RELATIONSHIP OF MOOD TO THE FREQUENCY OF IILNESS BEHAVIOR

\begin{tabular}{|c|c|c|c|c|c|c|}
\hline \multirow[b]{2}{*}{ Variable } & \multirow{2}{*}{$\begin{array}{c}\text { Score } \\
\text { on the } \\
\text { variable }\end{array}$} & \multirow[b]{2}{*}{ No. } & \multicolumn{3}{|c|}{$\begin{array}{c}\text { Men in } 3 \text { categories of } \\
\text { frequency of illness behavior }\end{array}$} & \multirow{2}{*}{$\begin{array}{c}\text { Significance } \\
\text { of } \\
\text { differences, } \\
\text { chi-square } \\
\text { analysis } \\
\text { with } 2 \text { d.f. }\end{array}$} \\
\hline & & & $\underset{\%}{\operatorname{Rare}}$ & $\begin{array}{c}\text { Inter- } \\
\text { mediate } \\
\%\end{array}$ & $\begin{array}{l}\text { Frequent } \\
\%\end{array}$ & \\
\hline $\begin{array}{l}\text { Aggressive mood } \\
\text { (includes only } \\
\text { men low on } \\
\text { anger-irritation) }\end{array}$ & $\begin{array}{l}\text { Low } \\
\text { High } \\
\text { Total }\end{array}$ & $\begin{array}{r}70 \\
69 \\
139\end{array}$ & $\begin{array}{l}45.7 \\
40.6 \\
43.2\end{array}$ & $\begin{array}{l}45.7 \\
43.5 \\
44.6\end{array}$ & $\begin{array}{r}8.6 \\
15.9 \\
12.2\end{array}$ & $\begin{array}{l}\chi^{2}=2.7 \\
P>0.20\end{array}$ \\
\hline $\begin{array}{l}\text { Aggressive mood } \\
\text { (includes only } \\
\text { men high on } \\
\text { anger-irritation) }\end{array}$ & $\begin{array}{l}\text { Low } \\
\text { High } \\
\text { Total }\end{array}$ & $\begin{array}{r}51 \\
112 \\
163\end{array}$ & $\begin{array}{l}52.9 \\
27.7 \\
35.6\end{array}$ & $\begin{array}{l}33.3 \\
48.2 \\
43.6\end{array}$ & $\begin{array}{l}13.7 \\
24.1 \\
20.9\end{array}$ & $\begin{array}{l}\chi^{2}=9.0 \\
P<0.02\end{array}$ \\
\hline $\begin{array}{l}\text { Jittery mood } \\
\text { (includes only } \\
\text { men low on } \\
\text { anger-irritation) }\end{array}$ & $\begin{array}{l}\text { Low } \\
\text { High } \\
\text { Total }\end{array}$ & $\begin{array}{r}94 \\
45 \\
139\end{array}$ & $\begin{array}{l}44.7 \\
40.0 \\
43.2\end{array}$ & $\begin{array}{l}45.7 \\
42.2 \\
44.6\end{array}$ & $\begin{array}{r}9.6 \\
17.8 \\
12.2\end{array}$ & $\begin{array}{l}\chi^{2}=1.9 \\
P>0.30\end{array}$ \\
\hline $\begin{array}{l}\text { Jittery mood } \\
\text { (includes only } \\
\text { men high on } \\
\text { anger-irritation) }\end{array}$ & $\begin{array}{l}\text { Low } \\
\text { High } \\
\text { 'Total }\end{array}$ & $\begin{array}{r}84 \\
79 \\
163\end{array}$ & $\begin{array}{l}47.6 \\
22.8 \\
35.6\end{array}$ & $\begin{array}{l}41.7 \\
45.6 \\
43.6\end{array}$ & $\begin{array}{l}10.7 \\
31.6 \\
20.9\end{array}$ & $\begin{array}{c}\chi^{2}=15.7 \\
P<0.0001\end{array}$ \\
\hline $\begin{array}{l}\text { Depressed mood } \\
\text { (includes only } \\
\text { men low on } \\
\text { anger-irritation) }\end{array}$ & $\begin{array}{l}\text { Low } \\
\text { High } \\
\text { Total }\end{array}$ & $\begin{array}{r}81 \\
58 \\
139\end{array}$ & $\begin{array}{l}43.2 \\
43.1 \\
43.2\end{array}$ & $\begin{array}{l}46.9 \\
41.4 \\
44.6\end{array}$ & $\begin{array}{r}9.9 \\
15.5 \\
12.2\end{array}$ & $\begin{array}{l}X^{2}=1.1 \\
P>0.50\end{array}$ \\
\hline $\begin{array}{l}\text { Depressed mood } \\
\text { (includes only } \\
\text { men high on } \\
\text { anger-irritation) }\end{array}$ & $\begin{array}{l}\text { Low } \\
\text { High } \\
\text { Total }\end{array}$ & $\begin{array}{r}56 \\
107 \\
163\end{array}$ & $\begin{array}{l}46.4 \\
29.9 \\
35.6\end{array}$ & $\begin{array}{l}46.4 \\
42.1 \\
43.6\end{array}$ & $\begin{array}{r}7.1 \\
28.0 \\
20.9\end{array}$ & $\begin{array}{l}\chi^{2}=10.7 \\
P<0.005\end{array}$ \\
\hline
\end{tabular}

arthritis and hypertension and did not belong to the frequent illness behavior group. Working with these 'pure' cases, then, it was noted that the scales individually do not fully differentiate each category from the other three. For example, on Scale $\mathrm{C}$, anger-irritation, arthritis and hypcrtension cases can be separated from the other two groups, which have higher scores, but not from each other. However, when Scale A is paired with Scale B or Scale C, as has been done in Tables 5 and 7 , then a definite suggestion of specificity is evident. That is, when a two-dimensional space with the two pairs of scales is constructed, then a particular diagnosis seems to be associated with a particular combination of scores. These findings are presented in Table 9 and Fig. 1 and explained in the following paragraph.

The data in Table 9 may be analyzed by either of two comparable statistical procedures: partitioning of chi-squarc $[36,37]$ or the likelihood ratio test $[38,39]$. Both methods furnish a straightforward analogy to the usual analysis of variance procedures. In the present instance, the likelihood ratio test is to be preferred because some of the expected cell frequencies are too small to justify the use of the chi-square statistic. The problem in Table 9 is treated as a three variate information transmission analysis [38] in which we are interested in the association between a 
Table 9. The relationship of Scales A, B and $C$ to positive diagnoses of Rheumatoid ARTHRITIS, HYPERTENSION, ULCER AND TO FREQUENT ILLNESS BEHAVIOR

\begin{tabular}{|c|c|c|c|c|c|c|c|c|c|c|}
\hline & & \multicolumn{2}{|c|}{$\begin{array}{l}\text { Rheumatoid } \\
\text { arthritis }\end{array}$} & \multicolumn{2}{|c|}{$\begin{array}{l}\text { Hyper- } \\
\text { tension }\end{array}$} & \multicolumn{2}{|c|}{ Ulcer } & \multicolumn{2}{|c|}{$\begin{array}{l}\text { Illness } \\
\text { behavior }\end{array}$} & \multirow[t]{3}{*}{$\begin{array}{l}\text { Chi-square values } \\
\text { with } 9 \text { d.f. }\end{array}$} \\
\hline & & \multirow[b]{2}{*}{ Low } & \multicolumn{7}{|c|}{ SCORES on SCALE B } & \\
\hline & & & High & Low & High & Low & High & Low & High & \\
\hline \multirow{4}{*}{$\begin{array}{l}\text { Score on } \\
\text { Scale A }\end{array}$} & Low & 3 & 3 & 12 & 5 & 4 & 10 & 2 & 2 & $\chi^{2}=18.8$ \\
\hline & High & 7 & 12 & 5 & 15 & 4 & 14 & 3 & 20 & $P<0.05$ \\
\hline & & \multicolumn{8}{|c|}{ Scores on Scale C } & \\
\hline & & Low & High & Low & High & Low & High & Low & High & \\
\hline \multirow{4}{*}{$\begin{array}{l}\text { Score on } \\
\text { Scale A }\end{array}$} & Low & 5 & 1 & 16 & 1 & 11 & 3 & 3 & 1 & $\chi^{2}=25.8$ \\
\hline & High & 13 & 6 & 14 & 6 & 4 & 14 & 8 & 15 & $P<0.001$ \\
\hline & & \multicolumn{8}{|c|}{ SCORES on COMBined SCALES B plus $C$} & \\
\hline & & Low & High & Low & High & Low & High & Low & High & \\
\hline \multirow{2}{*}{$\begin{array}{l}\text { Score on } \\
\text { Scale A }\end{array}$} & Low & 5 & 1 & 13 & 4 & 7 & 7 & 3 & 1 & \multirow{2}{*}{$\begin{array}{c}\chi^{2}=31.2 \\
P<0.001\end{array}$} \\
\hline & High & 12 & 7 & 12 & 8 & 4 & 14 & 3 & 20 & \\
\hline
\end{tabular}

joint classification (Scales A with B, A with C, and A with B plus C), and a third classification (disease category). The test yields a statistic, $\Lambda$, such that $-2 \log \Lambda$ is distributed as a $\chi^{2}$ with $(r s-1)(t-1)$ degrees of freedom. These $\chi^{2}$ values are reported in the last column of Table 9. The important point to note is that this test disregards any association between the two scales which form the joint classification. That is, it is like a chi-square test of complete independence of three attributes in a population from which we subtract the $\chi^{2}$ attributed to the association between the two scales.

The bottom of Table 9 summarizes the data by combining Scales B and C to obtain a single index of impulsiveness-control. This was done on the grounds that all of the results obtained thus far have suggested a functional similarity of Scales $\mathrm{B}$ and $\mathrm{C}$. The combining of the scales was accomplished by converting the raw scores for each individual into $z$-scores [40] and then adding them up.

Figure 1 is an attempt to present the data of Table 9 as a two-dimensional representation of the distances of each group from the other three. Since Scale A has a correlation of 0.52 with the combined B and C Scale, the axes are drawn at an angle of 58.7 degrees, instead of being orthogonal. This follows the common practice of representing the amount of correlation as the cosine of the angle. The intersection of the two scales, the origin or zero point, is set at the means of the scale scores of the remaining 186 men who do not fall into any of the disease categories. The units used on the axes are in standard deviations of the respective scales. The numbers in parentheses next to each disease category are the means for Scale A and for Scales B plus C, respectively. From Table 9 it can be seen that there are 25 arthritics, 37 hypertensives, 32 cases of ulcer, and 27 cases of frequent illness behavior. 


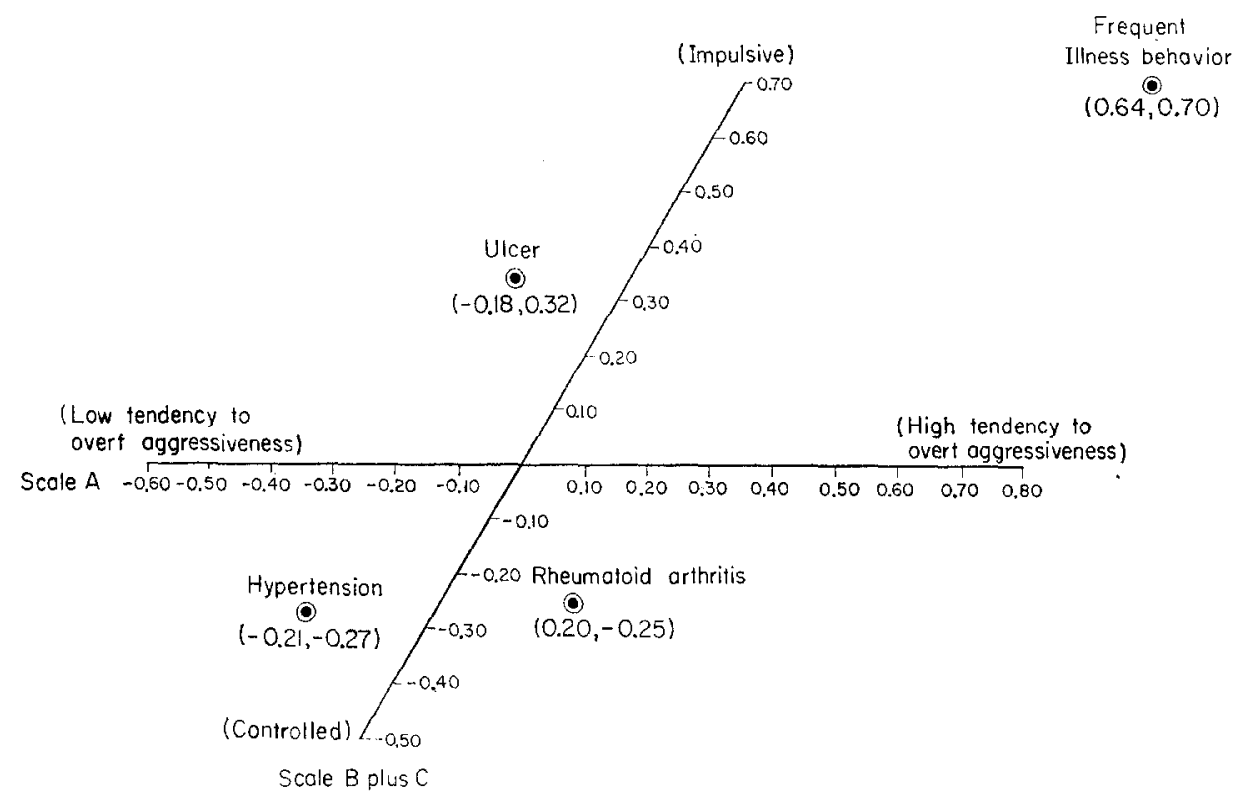

Fig. 1. The relationship of illness behavior and selected syndromes to Scale A and the combined Scale B plus Scale C.

Figure 1 may be summarized with the following tentative description of the four groups :

(1) Rheumatoid arthritics report urges to engage in overt aggressive behavior which they appear to control.

(2) Hypertensives also appear controlled, but they report a weak tendency toward overt aggressiveness.

(3) The ulcer cases report a weak tendency toward overt aggressiveness, but appear to be impulsive.

(4) The cases of frequent illness behavior are apparently not only impulsive, but they also report urges to engage in overt aggressive behavior.

\section{I S C U S S I O N}

There are a number of issues which must be raised in this section. The first problem concerns possible biases which might have influenced the results. There is evidence on the following factors: age, education, job status, and job environment. Age corrections were unnecessary whenever the variables-the Mood Scales, dispensary visits for illness, etc.- -were uncorrelated with age. Age was held constant for Table 9 because Scale B correlates slightly with age $(r=-0.15)$, as do the three diseases. The results, however, remained the same. Amount of education was not related to any variables or test data, except Scale $B(r=0.25)$, and no corrections were applied. Two other controls were tried and found unnecessary: (1) eliminating foremen and second line supervisors; (2) eliminating the men on the machine shop jobs; see previous discussion of these jobs. 
The findings concerning illness behavior would be strengthened if one had information on at least the following: (1) individual attitudes toward doctors and medical care; (2) frequency of illness behavior outside of company facilities. In the absence of such information, one can at least note that education and job status, two common indicators of social class, were unrelated to illness behavior. It is thus likely that attitudinal factors associated with social class are not playing an important role. With respect to the other problem, the possibility that men who visit the company dispensary less often simply visit private doctors more often, one can only note that such interpretation of the obtained findings suffers from the alternate difficulty of trying to explain why a particular group of men, like those, for example, who are low on Jittery mood and low on Scale A, the infrequent visitors to the company dispensary, should prefer to go to their own physicians.

The problem of interpreting the major findings can be outlined here but cannot be solved within the limits of available information. It resolves itself into two closely related issues: (1) what do the scales measure? (2) why should the scales, and the behavior they indicate, be related to illness behavior and to the various diagnoses?

Table 10. Intercorrelations of MoOd Scales and Scales A, B, and C*

\begin{tabular}{lcccccc} 
& Aggressive & Jittery & Depressed & Scale A & Scale B & Scale C \\
\hline Aggressive mood & - & & & & & \\
Jittery mood & 0.40 & - & & & \\
Depressed mood & 0.58 & 0.66 & - & - & \\
Scale A & 0.32 & 0.26 & 0.28 & 0.43 & - \\
Scale B & 0.36 & 0.30 & 0.31 & 0.42 & 0.38 & - \\
Scale C & 0.33 & 0.29 & 0.36 &
\end{tabular}

*All correlations are significant at $P<0.0001$.

Table 10 presents the intercorrelations of the Mood Scales and of Scales A, B, and $\mathrm{C}$. The pattern of correlations does not reveal any clear clustering of scales which might either suggest a way of grouping the measures or give additional insight into their meaning. The only correlations which are noticeably higher are those which relate the Mood Scales to each other and this, it may be supposed, reflects common method (test) variance. If one assumes that the intercorrelations in Table 10 reflect only one general trait, what might this trait be? It might be variously labeled as self-acceptance, willingness to report socially undesirable symptoms and tendencies, or the actual propensity for experiencing unpleasant and undesirable feelings. And one would then conclude that it is this ill-defined trait which is associated with the several diseases and with illness behavior. We have some limited evidence on Scales $A, B$ and $C$ : in a population of female undergraduates, these scales were negatively correlated - all around -0.44-with the EDwARDs Social Desirability Scale [33]. This suggests that future studies should be controlled for the tendency to give socially desirable responses.

However, the conclusion that only one general trait is being measured appears too limited. It has been shown that Scales B and C behave similarly, but clearly 
unlike Scale A. Furthermore, the effects of Scale A are enhanced when the scores on the other two scales are above a certain minimum. Finally, Fig. 1 demonstrates that one needs at least two dimensions to separate the several diagnostic groups from each other. It thus seems that there may be something specific about the effects of hostility-anger-aggression, and the control thereof, which makes it desirable to isolate them from the presumably more general effects of low self-acceptance. In other words, the three scales may be partial indicators of some possibly disruptive or 'pathogenic' effects of conflicts over aggression.

This conclusion that the arousal and expression of aggression and anger are possibly important factors in the study of illness behavior in general and some diseases in particular, can be made plausible by references to diverse writings. Many social scientists have assumed that because our society regulates the expression of aggression, conflicts over aggression will be relatively common. The deterrent forces in such conflicts are often labeled as anticipation of punishment [25], moral standards [41], or simply aggression anxiety [42]. Writers on psychosomatic illnesses, such as ALEXANDER [43], have implicated conflict over aggression in the etiology of most of the major diseases they discuss. Finally, there are studies which have successfully related arousal of anger and arousal of conflict over aggressionanger to physiological changes [44-48].

However, as the recent reviews of the literature have emphasized [49-52], the problems of conceptualization and measurement of aggression are so considerable that definitive interpretations of results and comparisons across studies using different measures are well-nigh impossible. Moreover, it appears very unlikely that aggression refers to unitary behavior; rather, it seems necessary to break down the concept. Buss's [51] separation into aggression, anger, and hostility is one possible classification. Another possibility is AleXANDER's [43] description of a fully consummated aggressive attack in terms of three phases: conceptual (planning and fantasies), vegetative preparation, and muscular activity.

The present writers are not confident that their measures can be unambiguously related to other aggression-anger-hostility measures available in the literature, nor are they sure of the referents in observable behavior which these scales may indicate. In view of these limitations, any attempts at interpretation beyond the small hints already offered would be clearly inappropriate. Suffice it to note that the results seem to warrant additional investigations.

Future work on illness behavior may also profit from a closer look at studies dealing with the problem of volunteering for experiments [53-55]. The two kinds of self-selection biases, volunteering to be a patient and volunteering to be a subject, are suggestively similar and may have some common personality and situational correlates. For example, SchubERT [55] found that among those variables which differentiated volunteers from non-volunteers were higher rates of smoking, more feelings of hostility, and greater fluctuations of mood.

S U M M A R Y

In the expanding field of medical sociology, the frequency of visits to a free medical facility has become an important form of illness behavior. Such behavior not only reflects the individual's physical health, but also his perception of it, and his decision what to do about it. Involved here are also his attitudes toward 
doctors and medical care, his psychological make-up, and his phenomenological well-being. Various studies have been able to relate the frequency of dispensary visits to such variables as occupational status, self-esteem and self-acceptance, perceived stress, and the readiness to assume the sick role.

The present study was concerned with relating the frequency of dispensary visits to the following variables: disturbances of mood (reported well-being) and selfreport measures of aggressive tendencies and of control over impulsiveness and over feelings of anger. The same variables were also related to three diagnostic categories: rheumatoid arthritis, hypertension, and ulcer. The major findings, obtained on an industrial population of over 300 male workers, arc summarized below:

1. Subjects who obtained high scores on the Mood Scales labeled Aggressive, Jittery, and Depressed had a greater frequency of illness behavior (dispensary visits for illness and illness absences).

2. Subjects who scored high on a self-report scale reflecting a tendency to engage in overt aggressive behavior, had a greater frequency of illness behavior.

3. The above test and questionnaire data were unrelated to control variables, not indicative of illness behavior: hernia, dispensary visits for injuries, and absences for personal leaves.

4. When the measures of control over impulsiveness and over feelings of anger were considered jointly with the other scales, then it was apparent that the amount of control affects the association of illness behavior with mood and overt aggressiveness: strong control reduces the association and weak control enhances it.

5. If the scales reflecting tendency to engage in overt aggressive behavior and to control impulsiveness and angry feelings are used to construct a two-dimensional space, then the following placements of the different diagnostic categories are possible :

(a) Hypertensive men tend to be low on overt aggressiveness and high on control.

(b) Rheumatoid arthritics tend to be high on overt aggressiveness and high on control.

(c) Men with ulcers tend to be low on overt aggressiveness and low on control.

(d) Subjects with a high frequency of illness behavior tend to be high on overt aggressiveness and low on control.

Acknowledgements-It is a pleasure to acknowledge the extensive assistance of Dr. ThOMAS A. Lincoln and Mrs. Margery Sealand in the collection of the data, and of Dr. Dean Clyde in providing and analyzing the mood scales.

This work has been supported in part by the following grants from the National Institutes of Health : A-308, A-1607, MH-09177, and MK-K6 16709.

\section{REFERE N CES}

1. Halliday, J. L.: Psychosocial Medicine. Norton, New York, 1948.

2. Stoeckle, J. D. and Davimson, G. E.: Bodily complaints and other symptoms of depressive reaction, J. Amer. med, Ass. 180, 134, 1962.

3. Parsons, T.: The Social System. The Free Press, Glencoe, Ill., 1951.

4. Koos, E. L.: The Health of Regionville. Columbia University Press, New York, 1954.

5. DEASY, L. C.: Socioeconomic status and participation in the poliomyelitis vaccine trial, A mer. sociol. Rev. 21, 185, 1956.

6. Glasser, M. A.: Study of the public's acceptance of the Salk vaccine program, Amer. J. publ. Hlth 48, 141, 1958.

7. Graham, S.: Socio-economic status, illness, and the use of medical services, in Patients, Physicians, and Illness. Ed. by JACO, E. G. The Free Press, Glencoe, Ill., 1958. 
8. Redlich, F. C., Hollingshead, A. B. and Bellis, E.: Social class differences in attitudes toward psychiatry, Amer. J. Orthopsychiat. 25, 60, 1955.

9. Gurin, G., Veroff, J. and Feld, S.: Americans View Their Mental Health. Basic Books, New York, 1960.

10. Mechanic, D.: The concept of illness behavior, J. chron. Dis. 15, 189, 1962.

11. Jaco, E. G.: Patients, Physicians, and Illness. The Free Press, Glencne, Ill., 1958

12. KIng, S. H.: Perceptions of Illness and Medical Practice. Russell Sage Foundation, New York, 1962.

13. Rosenstock, I. M.: What research in motivation suggests for public health, Amer. J. publ. Hlth 50, 295, 1960.

14. Mechanic, D. and Volkart, E. H.: Stress, illness behavior, and the sick role, Amer. sociol. Rev. 26, 51, 1961.

15. Mechanic, D. and Volzart, E. H.: Illness behavior and medical diagnosis, J. Hlth hum. Behav. 1, 86, 1960.

16. Roessler, R. and Greenfield. N. S.: Personality determinants of medical clinical consultation, J. nerv. ment. Dis. 127, 142, 1958.

17. Fiedler, F. E., Dodge, J. S., Jones, R. E. and Hutchins, E. B.: Interrelations among measures of personality adjustment in non-clinical populations, J.abnorm. soc. Psychol. 56, 345, 1958.

18. KASL, S. V.: Some effects of occupational status on physical and mental health. Unpublished Doctoral Dissertation, University of Michigan, Ann Arbor, Mich., 1962.

19. KASL, S. V. and FRENCH, J. R. P., Jr.: The effects of occupational status on physical and mental health, J. soc, Issues 18, 67, 1962.

20. U.S. Department of the Army, Office of the Deputy Chief of Stafl for Personnel: Sick Leave Study, Army Progress Report TP-3, Part 3, 1, 1960.

21. Hollingshead, A. B. and Redich, F. C.: Social Class and Mental Illness. Wiley, New York, 1958.

22. INKELES, A.: Industrial man: the relation of status to experience, perception, and value, Amer. J. Sociol. 66, 1, 1960.

23. HinkLe, L. E., Jr., and WoLfF, H. G.: Health and the social environment: experimental investigations, in Explorations in Social Psychiatry, p. 105. Ed. by Lerghton, A. H., Clauden, J. A. and Wilson, R. N. Basic Books, New York, 1957.

24. Hinkıe, L. E., Jr., and WolfF, H. G: : Ecologic investigations of the relationship between illness, life experiences, and the social environment, Ann. intern. Med. 49, 1373, 1958.

25. Dollard, J., Doob, L. W., Miller, N. E., Mowrer, O. H. and Sears, R. R.: Frustration and Aggression. Yale University Press, New Haven, 1939.

26. Henry, A. F. and Short, J. F., Jr.: Suicide and Homicide. The Free Press, Glencoe, III., 1954.

27. Ropes, M. W., Bennett, G. A., CobB, S., Jacox, R. and Jessar, R. A.: 1958 revision of diagnostic criteria for rheumatoid arthritis, Bull. rheum. Dis. 9, 175, 1958.

28. LinCOLN, T, A. and COBB, S.: The prevalence of mild rheumatoid arthritis in industry, J. occup. Med. 5, 10, 1963.

29. DunN, J. P. and CoвB, S.: Frequency of peptic ulcer among executives, craftsmen, and foremen, J. occup. Med. 4, 343, 1962.

30 Metropolitan Life Insurance Company: Statist. Bull. 40, Nov./Dec. 1959.

31. Cunde, D. J.: Clyde Mood Scale, National Institute of Mental Health, Bethesda, Maryland, 1959.

32. Clyde, D. J.: Self-ratings, in Drugs and Behavior, p. 583. Ed. by Uhr, L. and Miller, J. G. Wiley, New York, 1960.

33. EDwards, A. L.: The Social Desirability Variable in Personality Assessment and Research. The Dryden Press, New York, 1957.

34. Cronbach, L. J.: Further evidence on response sets and test design, Educ, psychol. Measmt. 10, 3, 1950 .

35. CAmpbell, D. T. and Fiske, D. W.: Convergent and discriminate validation by the multitrait-multimethod matrix, Psychol. Bull. 56, 81, 1959.

36. Winer, B. J.: Statistical Principles in Experimental Design. MœGraw-Hill, New York, 1962.

37. Yule, G. U. and Kendall, M. G.: An Introduction to the Theory of Statistics. Hafner, New York, 1950.

38. McGiLl, W. J.: Multivariate information transmission, Psychometrika 19, 97, 1954.

39. MooD, A. M.: Introduction to the Theory of Statistics. McGraw-Hill, New York, 1950.

40. Guilford, J. P.: Fundamental Statistics in Psychology and Education. MoGraw-Hill, New York, 1956. 
41. Miller, D. R. and Swanson, G. E.: Inner Conflict and Defense. H. Holt, New York, 1960.

42. Lesser, G. L.: Conflict analysis of fantasy aggression, J. Personality 26, 29, 1958.

43. Alexander, F.: Psychosomatic Medicine. W. W. Norton, New York, 1950.

44. Ax, A. F.: The physiological differentiation between fear and anger in humans, Psychosom. Med. 15, 433, 1955.

45. Cohen, S. I. and Silverman, A. J.: Psychophysiological investigations of vascular response variability, J. psychosom. Res. 3, 185, 1959.

46. Funkenstein, D. H., King, S. H. and Droletie, M. E.: Mastery of Stress. Harvard University Press, Cambridge, Mass., 1957.

47. KIng, S. H. and Henry, A. F.: Aggression and cardiovascular reactions related to parental control over behavior, J. abnorm. soc. Psychol. 50, 206, 1955.

48. Schachter, J.: Pain, fear, and anger in hypertensives and normotensives: a psychophysiological study, Psychosom. Med. 17, 29, 1957.

49. Berkowitz, L.: The expression and reduction of hostility, Psychol. Bull. 55, 257, 1958.

50. Berkowitz, L.: Aggression: A Social Psychological Analysis. McGraw-Hill, New York, 1962.

51. Buss, A. H.: The Psychology of Aggression. Wiley, New York, 1961.

52. MCNeIL, E. B. : Psychology and aggression, J. conflict Res. 3, 195, 1959.

53. HowE, E. S.: Quantitative motivational differences between volunteers and non-volunteers for a psychological experiment, J. appl. Psychol. 44, 115, 1960.

54. Lasagna, L. and von Felsinger, J.: The volunteer subject in research, Science 120, $359,1954$.

55. Schubert, I. S. P.: Volunteering as arousal seeking, Amer. Psychologist 15, 413, 1960. 